\title{
Ethephon as a potential tool to manage alternate bearing of 'Fuji' apple trees
}

\author{
Mateus da Silveira Pasa ${ }^{1}$ (D), Bruno Carra², Alberto Fontanella Brighenti ${ }^{3}$, \\ Felipe Augusto Moretti Ferreira Pinto ${ }^{4}$, Paulo Celso de Mello-Farias ${ }^{1}$, Flávio Gilberto Herter ${ }^{1}$
}

$10.1590 / 0034-737 X 202168030003$

\begin{abstract}
The objective of this study was to investigate the effect of different rates of ethephon on return bloom and yield, and fruit quality of 'Fuji' apple trees. The experiment was performed during the 2014/2015 and 2015/2016 growing seasons. Eighteen-year-old Fuji Standard apple trees grafted on M.9 were sprayed with different rates of ethephon (300 mg L-1, $400 \mathrm{mg} \mathrm{L}^{-1}$, and $500 \mathrm{mg} \mathrm{L}^{-1}$ ) 30 days after full bloom (DAFB) and compared to an unsprayed control. Yield components (number of fruit per tree, yield, fruit weight, and estimated yield) and fruit quality attributes (fruit firmness, total soluble solids and starch-iodine index) were evaluated in both seasons. Return bloom (percentage of flowering spurs and 1-year-shoots) was assessed only the year following the application. Our results show that ethephon increases return bloom and yield of 'Fuji Standard' apple trees, without affecting fruit quality attributes.
\end{abstract}

Keywords: Malus dometica Borkh; return bloom; return yield; flower bud differentiation.

\section{INTRODUCTION}

Apple is the second temperate fruit tree most produced in Brazil (Pasa et al., 2016), mainly in the states of Rio Grande do Sul (46.3\%) and Santa Catarina (50.1\%) (IBGE, 2016). While 'Gala' is the main cultivar planted in most growing areas, 'Fuji' represents $56 \%$ of the apples grown in the region of São Joaquim. This cultivar is described as susceptible to alternate bearing (Atay et al., 2013). Alternate bearing may be affected by cultivar (Monselise \& Goldschmidt, 1982) and is characterized by large yields of small sized fruit in "on" years, and low yields, sometimes even no fruit, in “off” years (Guitton et al., 2011).

Alternate bearing is affected by several factors, among which the most important seem to be the influence of plant hormones, by either inhibiting or inducing flower bud initiation (Jonkers, 1979). The inhibitory effects of seed-derived gibberellins on flower bud initiation in apple is widely known. However, recent studies suggest that gibberellins influence, but do not control, this complex process (Schmidt et al., 2009). Then, spraying gibberellins as means reduce flower bud initiation and achieve more regular crops may not be the best option. Managing the trees to initiate more flowers instead of reducing it seems to be more reasonable, since high yields of "on" years would be maintained and yields of "off" years increased.

An adequate chemical thinning program has the potential do reduce the biennial behavior of apples. However, cultivars with strong natural tendency for alternate bearing may show alternate habit even after a successful reduction of crop load by chemical thinning (McArtney et al., 2013). In this case, additional strategies might be required to manage alternate bearing. The application of ethephon coinciding with flower bud initiation has shown promising results to increase return bloom and yield in pome trees. Several studies have reported the efficiency of ethephon to increase return bloom in apples (Duyvelshoff \& Cline, 2013; McArtney et

\footnotetext{
Submitted on May 21 $1^{\text {st }}, 2020$ and accepted on November 15 th, 2020.

${ }^{1}$ Universidade Federal de Pelotas, Departamento de Fitotecnia, Capão do Leão, Rio Grande do Sul, Brazil. mateus.pasa@gmail.com; mellofarias@yahoo.com.br; flavioherter@gmail.com

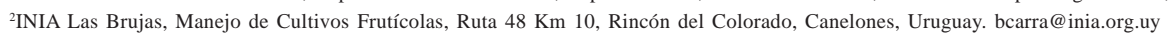

${ }^{3}$ Universidade Federal de Santa Catarina, Departamento de Fitotecnia, Florianópolis, Santa Catarina, Brazil. alberto.brighenti@ufsc.br

${ }^{4}$ Empresa de Pesquisa Agropecuária e Extensão Rural de Santa Catarina, Estação Experimental de São Joaquim, São Joaquim, Santa Catarina, Brazil. felipepinto@epagri.sc.gov.br
} 
al., 2013) and pear (Einhorn et al., 2014) with varying rates, number of applications, time of application, and cultivars. Such results are not available for 'Fuji' in the Brazilian conditions, which is, as mentioned before, very susceptible to alternate bearing. Ethephon is also an alternative for chemical thinning for apple (Petri et al., 2018) and peach (Giovanaz et al., 2016), but its effect is highly dependent on climatic conditions before and after spraying.

Given the limited availability of information regarding the management of alternate bearing of 'Fuji' apple trees in Brazil, and the potential positive economic impact of reducing its effects for apple growers, the objective of this study was to investigate different rates of ethephon on return bloom and yield, and fruit quality atributtes of 'Fuji' apple trees.

\section{MATERIAL AND METHODS}

The study was performed in São Joaquim, at the Experimental Station of São Joaquim/EPAGRI, located in São Joaquim, Santa Catarina State, Brazil (28¹7'39' S, $49^{\circ} 55^{\prime} 56^{\prime \prime} \mathrm{W}$, at $1,415 \mathrm{~m}$ of altitude), during the growing seasons of 2014/2015 and 2015/2016. According to Köppen-Geiger classificaton, the climate of the region is mesothermal humid (Cfb) i.e, temperate climate constantly humid, without dry season, and cool summer (Benez, 2005), and average chill accumulation (temperatures below $7,2{ }^{\circ} \mathrm{C}$ ) is 900 hours. Climatic conditions during the experiment were recorded and are shown in Figure 1. According to the Brazilian soil classification system (Santos et al., 2013), the soil of the experimental field is a Cambissolo Húmico (Inceptisol),

Eighteen year-old Fuji Standard apple trees grafted on M.9, trained to a central-leader system, were used as plant material, and as pollinator two adjacent rows of 'Gala' were planted. Row spacing was $4 \mathrm{~m}$ and within-row spacing, i.e., between trees in the row, was $1.0 \mathrm{~m}(2,500$ trees $\left.\mathrm{ha}^{-1}\right)$. Orchard management was performed according the recommendations of the apple production system (Epagri, 2006). The experiment was arranged in a randomized complete block design with four replicates. Each replication consisted of three trees, but only the central one was used for evaluation, leaving one at each end as border).

Treatments consisted on Ethephon sprayed at different rates (300 $\mathrm{mg} \mathrm{L}^{-1}, 400 \mathrm{mg} \mathrm{L}^{-1}$, and $500 \mathrm{mg} \mathrm{L}^{-1}$ ) and an unsprayed control. Trees were sprayed in the "on" year (2014/2015 growing season) 30 days after full bloom. The date of full bloom was 09/25/2014. The source of ethephon was the commercial product Ethrel® (24\% a.i. w:v, Bayer CropScience). A nonionic surfactant (BreakThru, BASF Corp.) was added in all solutions at a rate of $0.05 \%$ (v:v) of. Trees were sprayed with a motorized handgun backpack sprayer (Stihl SR 450) to runoff, with a flow rate of $2.64 \mathrm{~L} \mathrm{~min}^{-1}$ (spraying volume of approximately $\left.1000 \mathrm{~L} \mathrm{ha}^{-1}\right)$.

At commercial maturity, fruit were harvested according to starch-iodine index (4-5), flesh firmness (70-90 N), and soluble solids (11-12 ${ }^{\circ}$ Brix), in 03/17/2015 and 03/13/2016. Total number of fruit per tree was counted and weighed (kg), with a digital scale (UR 1000 Light, URANO). From these data, yield per tree $(\mathrm{kg})$, fruit weight $(\mathrm{g})$ and estimated yield (ton ha ${ }^{-1}$ ) were calculated. Since Ethephon may have a thinning effect on apples, in the season of treatment $(2014 / 2015)$ the number of fruit thinned per tree was recorded approximately 45 DAFB. Return bloom was assessed the year after the year of treatment at full bloom (09/24/2015) from representative scaffolds (at least 100 flower clusters) of each tree. The total number of spurs and 1-year-old shoots (with and without flower clusters) was counted and return bloom expressed as the percentage of flowering spurs and 1-year-old shoots. In both growing seasons, samples of 15 fruit per replicate (tree) were taken at harvest for flesh firmness, soluble solids content and starch-iodine index determination, according to methodology described by Pasa et al. (2018).

The R software (R Core Team, 2014) was used to perform statistical analysis. Data expressed as percentage or counts were transformed by $\arcsin$ [square root $(n+1)$ ] and square root $(n+1)$. Data were analyzed for statistical significance by means of F test, and when significant, regression analysis was performed.

\section{RESULTS AND DISCUSSION}

Ethephon did not significantly affect yield components in the season of application (Table 1).

In the season following application the percentage of spurs flowering was significantly increased by ethephon, regardless the rate (Figure $2 \mathrm{~A}$ ). On the other hand, the percentage of flowering 1-year-shoots was not affected (Figure 2B). Similar effect was observed for yield (Figure 2C), estimated yield (Figure 2D) and number of fruit per tree (Figure 2E).

Despite the greater crop load of ethephon treated trees the year following application, no differences in fruit size were observed (Figure 2F). Regardless the treatment, fruit size was considerable small in this season, which was likely an effect of late thinning performed in this block ( 70 DAFB), which occurred due to operational issues, but was similar to all treatments. Fruit quality attributes did not differ among treatments in both growing seasons (Table 2).

Our results show that exogenous application of ethephon increases return bloom and yield of 'Fuji' apple trees. Similar effect was observed in other biennial apple cutlivars, like Golden Delicious, York Imperial (McArtney et al., 2013), and Redchief Delicious (Bukovac et al., 2006). 
McArtney et al. (2013) observed increased return bloom of spurs $(43.3 \%)$ of 'Golden Delicious' in response to ethephon (560 $\left.\mathrm{mg} \mathrm{L}^{-1}\right)$ sprayed 50 + 80 DAFB, while control trees had only $10.9 \%$ of spurs flowering. These authors also observed that the transition to floral development started 64 DAFB but peaked around 85 DAFB. When the transition is visible in the microscope (based on the doming of the axillary meristem), the induction has already occurred.

Based on this information, one might think that substances to induce flowering should be sprayed around 60 DAFB. However, a study in apple at the genetic level showed that flower bud induction seems to occur around 30 DAFB, before the first visible morphological changes in apical meristem occur (Hättasch et al., 2008). Indeed, our results show that buds are responsive to exogenous ethephon application at this time, also suggesting that flower bud induction occurs early in the season.

Regardless the rate, estimated yield of ethephon treated trees was significantly greater than control the season following the treatment (off year). Einhorn et al.
(2014) observed greater return bloom and yield of 'D'Anjou' pears treated with ethephon $300 \mathrm{mg} \mathrm{L}^{-1} 87$ DAFB. Bukovac et al. (2006), observed similar results with Redchief 'Delicious' apple, in response to ethephon 200 $\mathrm{mg} \mathrm{L}^{-1}$, sprayed $21+42$ DAFB and $21+42+63$ DAFB. These authors also observed that at the end of the sixyear study, the mean yield per tree of ethephon treated trees was similar to control trees, but ethephon reduced the variation in yield between "on" and "off" years. Even though mean yield was similar, achieving regular crops over the years has a dramatic impact on tree physiology and orchard management. For example, an orchard of 'Fuji' apples in an "off" year is very difficult to manage. Firstly, this cultivar is vigorous, so a low crop load means greater vegetative growth and consequently more summer pruning (or other strategies to control vegetative growth) is needed in order to allow good light penetration for flower bud formation and fruit color. Secondly, fruit of these trees may show greater incidence of post-harvest physiological disorders like "bitter pit", which is more severe in vigorous trees (Jemriæ et al., 2016).

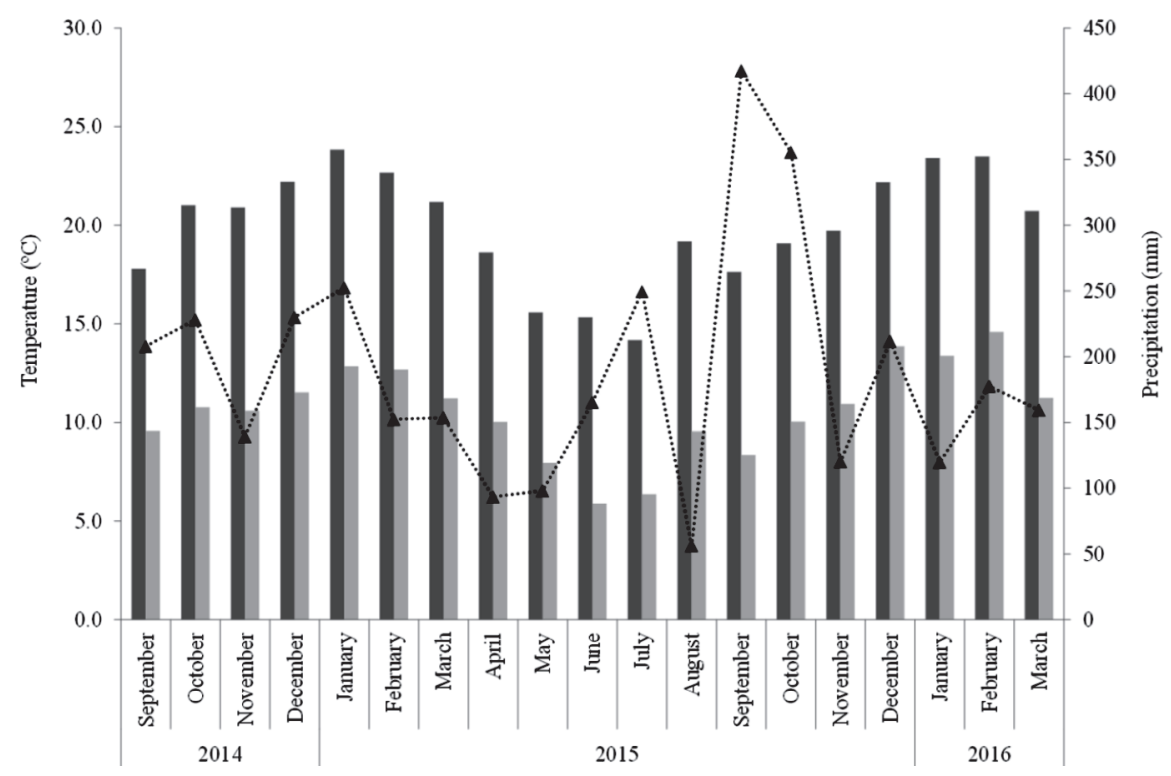

Figure 1: Climatic conditions of the experimental field, from 2014 to 2016.

Table 1: Yield components of 'Fuji Standard' apple trees in response to Ethephon sprayed 30 days after full bloom in the growing season of 2014/2015

\begin{tabular}{lccccc}
\hline $\begin{array}{l}\text { Ethephon rate } \\
\left(\mathbf{m g ~ L}^{-1}\right)\end{array}$ & $\begin{array}{c}\text { Fruit } \\
\text { thinned }\end{array}$ & $\begin{array}{c}\text { Fruit } \\
\left(\mathbf{n}^{\circ} \text { tree }^{-1}\right)\end{array}$ & $\begin{array}{c}\text { Yield } \\
\left(\mathbf{k g ~ t r e e}^{-1}\right)\end{array}$ & $\begin{array}{c}\text { Estimated yield } \\
\left(\text { ton ha } \mathbf{~ h a ~}^{-1}\right)\end{array}$ & $\begin{array}{c}\text { Fruit weight } \\
(\mathbf{g})\end{array}$ \\
\hline 0 & 119.3 & 276.9 & 38.2 & 95.5 & 138.5 \\
300 & 137.0 & 288.5 & 43.2 & 108.1 & 149.7 \\
400 & 130.8 & 290.3 & 41.5 & 103.7 & 142.6 \\
500 & 131.7 & 285.8 & 42.5 & 106.3 & 148.0 \\
$p$ & $\mathrm{~ns}$ & $\mathrm{~ns}$ & $\mathrm{~ns}$ & $\mathrm{~ns}$ & $\mathrm{~ns}$ \\
\hline
\end{tabular}

ns $=$ not significant

Rev. Ceres, Viçosa, v. 68, n.3, p. 180-184, may/jun, 2021 

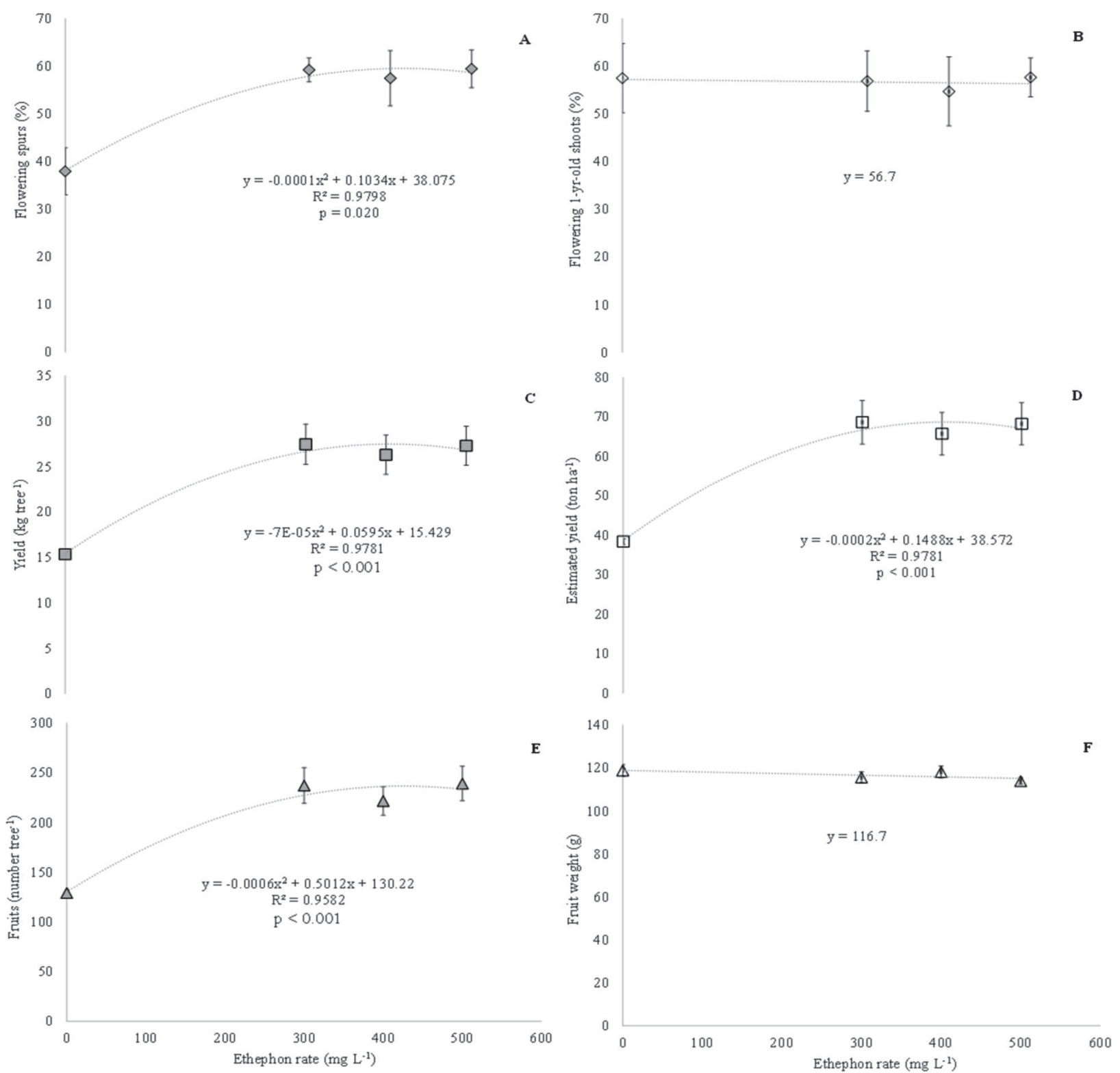

Figure 2: Return bloom and yield components of 'Fuji Standard' apple trees in the growing season of 2015/2016, in response to ethephon sprayed at different rates the previous season. Vertical bars represent SE $(n=4)$.

Table 2: The effect of ethephon on fruit quality attributes of 'Fuji Standard' apples in the season of application (2014/2015) and the season following the application $(2015 / 2016)$

\begin{tabular}{lccc}
\hline Ethephon rate $\left(\mathbf{m g ~ L}^{\mathbf{- 1}}\right)$ & Flesh firmness $($ Newton) & Total soluble solids $\left({ }^{\circ}\right.$ Brix) & Iodine-starchindex \\
\hline & & $\mathbf{2 0 1 4 - 2 0 1 5}$ & 6.4 \\
0 & 74.6 & 12.0 & 6.6 \\
300 & 75.7 & 12.4 & 6.5 \\
400 & 73.3 & 12.3 & 6.3 \\
500 & 74.4 & 11.9 & $\mathrm{~ns}$ \\
$\mathrm{n}$ & $\mathrm{ns}$ & $\mathrm{ns}$ & 4.8 \\
\hline & & $\mathbf{2 0 1 5 - 1 6}$ & 4.7 \\
0 & 80.7 & 11.6 & 4.9 \\
300 & 80.3 & 12.1 & 4.5 \\
400 & 81.2 & 12.0 & $\mathrm{~ns}$ \\
500 & 80.0 & 11.7 & $\mathrm{~ns}$ \\
$\mathrm{p}$ & $\mathrm{ns}$ & & \\
\hline
\end{tabular}

ns $=$ not significant 
Ripening in climacteric fruit is associated with a great increase in ethylene production and can be induced by exogenous ethylene (Silva et al., 2012; Hiwasa et al., 2003). Since apples are climacteric, we might expect ripening changes following the application of ethephon. However, we did not observe such effect in fruit of trees sprayed with ethephon, even in the season of application. This is probably because ethephon was sprayed early in the season (30 DAFB), and at this time ripening is little affected by exogenous ethylene, since they are in early stages of development.

\section{CONCLUSIONS}

Collectively, our results show that ethephon, sprayed approximately 30 days after full bloom, with rates varying from 300 to $500 \mathrm{mg} \mathrm{L}^{-1}$, reduces alternate behavior of 'Fuji Standard' apple trees by increasing return bloom and yield, without negatively affecting yield and fruit quality in the year of application. We strongly suggest first time applications to be performed in small areas, since the application of plant growth regulators like ethephon, may be affected by climatic conditions, tree age, nutrition, sanitary conditions, among others, which vary among orchards.

The results found in the present study are new and promising as means to reduce the negative effects of alternate bearing of 'Fuji' apple trees and promote regular yields of high-quality fruit. While our results are promising, we encourage future studies to investigate the effects of ethephon and other compounds in other growing regions, as well as testing additional rates, application timings, influence on post-harvest, among other potential implications.

\section{ACKNOWLEDGEMENTS, FINANCIAL SUPPORT AND FULL DISCLOSURE}

The authors would like to acknowledge the Empresa de Pesquisa Agropecuária e Extensão Rural de Santa Catarina (EPAGRI) for financial support.

The authors would like also to inform that there is no conflict of interests in carrying this research and publishing the manuscript.

\section{REFERENCES}

Atay AN, Koyuncu F \& Atay E (2013) Relative susceptibility of selected apple cultivars to alternate bearing. Journal of Biodiversity and Environmental Sciences, 7:81-86.

Benez MC (2005) Dados e informações biofísicas da Unidade de Planejamento Regional Planalto Sul Catarinense UPR 3. In: Dufloth JH, Cortina N, Veiga M \& Mior LC (Ed.) Estudos básicos regionais de Santa Catarina. Florianópolis, Epagri. 76p.

Bukovac MJ, Sabbatini P \& Schwallier PG (2006) Modifying alternate bearing of spur-type 'Delicious' apple with ethephon. HortScience, 41:1606-1611.
Duyvelshoff C \& Cline JA (2013) Ethephon and prohexadionecalcium influence the flowering, early yield, and vegetative growth of young 'Northern Spy' apple trees. Scientia Horticulturae, 151:128-134.

Einhorn T, Pasa M \& Turner J (2014) 'D'Anjou' pear shoot growth and return bloom, but not fruit size, are reduced by prohexadione-calcium. HortScience, 49:180-187.

EPAGRI - Empresa de Pesquisa Agropecuária e Extensão Rural de Santa Catarina (2006) A cultura da macieira. Florianópolis, EPAGRI. 743p.

Giovanaz MA, Amaral PA, Pasa MS, Lima APF, Weber D \& Fachinello JC (2016) Chemical thinning affects yield and return flowering in 'Jubileu' peach. Revista Ceres, 63:329-333.

Petri JL, Francescatto P, Sezerino AA, Gabardo GC \& De Martin MS (2018) Alternativas de raleio químico da macieira 'Fuji suprema'. Revista Agropecuária Catarinense, 31:74-81.

Guitton B, Kelner JJ, Velasco R, Gardiner S, Chagné D \& Costes E (2011) Genetic control of biennial bearing in apple. Journal of Experimental Botany, 63:131-149.

Hättasch C, Flachowsky H, Kapturska K \& Hanke MV (2008) Isolation of flowering genes and seasonal changes in their transcript levels related to flower induction and initiation in apple (Malus x domestica). Tree Physiology, 28:1459-1466.

Hiwasa K, Kinugasa Y, Amano S, Hashimoto A, Nakano R, Inaba A \& Kubo Y (2003) Ethylene is required for both the initiation and progression of softening in pear (Pyrus communis L.) fruit. Journal of Experimental Botany, 54:771-779.

IBGE - Instituto Brasileiro de Geografia e Estatística (2016) SIDRA/Produção Agrícola Municipal. Available at: <https:// sidra.ibge.gov.br/tabela/1613>. Accessed on: December 18 ${ }^{\text {th }}, 2018$.

Jemriæ T, Fruk I, Fruk M, Radman S, Sinkoviè L \& Fruk G (2016) Bitter pit in apples: pre- and postharvest factors: A review. Spanish Journal of Agricultural Research, 14:01-12.

Jonkers H (1979) Biennial bearing in apple and pear: a literature survey. Scientia Horticulturae, 11:303-317.

Mcartney SJ, Greene D, Schmidt T \& Yuan R (2013) Naphthaleneacetic acid and ethephon are florigenic in the biennial apple cultivars Golden Delicious and York Imperial. HortScience, 48:742-746.

Monselise S \& Goldschmidt E (1982) Alternate bearing in fruit trees. Horticultural Reviews, 4:128-173.

Pasa MS, Felippeto J, Nava G, Silva CP, Brighenti AF \& Ciotta MN (2018) Performance of 'Fuji Suprema' apple trees treated with budbreak promoters, in São Joaquim-SC. Revista Brasileira de Fruticultura, 40:e-325.

Pasa MS, Katsurayama JM, Brighenti AF, Araújo Filho JV \& Boneti JIS (2016) Desempenho de macieiras 'Imperial Gala' e 'Mishima Fuji’ em diferentes porta-enxertos. Pesquisa Agropecuária Brasileira, 52:17-26.

R Core Team. R: A language and environment for statistical computing. (2014). R Foundation for Statistical Computing, Vienna, Austria. Available at: <http://www.R-project.org/>. Accessed on: March18 $8^{\text {th }}, 2020$.

Santos HG, Jacomine PKT, Anjos LHC, Oliveira VA, Lumbreras JF, Coelho MR, Almeida JA, Cunha TJ F \& Oliveira JB (2013) Sistema brasileiro de classificação de solos. $3^{\text {rd }}$ ed. Brasília, Embrapa. 353p.

Schmidt T, Elfving DC, Mcferson JR \& Whiting MD (2009) Crop load overwhelms effects of gibberellic acid and ethephon on floral initiation in apple. HortScience, 44:1900-1906.

Silva DFP, Salomão LCC, Siqueira DL, Cecon PR \& Rocha A (2012) Manga 'Ubá' tratada com ethephon na pré-colheita. Revista Ceres, 59:555-559. 